\title{
Clerodane-type Diterpene Glycosides from Dicranopteris pedata
}

\author{
Bei-Bei Gao ${ }^{2} \cdot$ Yu-Fei Ou ${ }^{1,2} \cdot$ Qin-Feng Zhu ${ }^{3} \cdot$ Zhi-Ping Zhou $^{1,2} \cdot$ Zhen-Tao Deng $^{1,2} \cdot$ Meng Li $^{1,2} \cdot$ Qin-Shi Zhao $^{2}$
}

Received: 22 April 2021 / Accepted: 29 May 2021 / Published online: 5 June 2021

(c) The Author(s) 2021

\begin{abstract}
Three new clerodane-type diterpene glycosides, $(5 R, 6 S, 8 R, 9 S, 10 R)-6$ - $O$-[ $\beta$-D-glucopyranosyl- $(1 \rightarrow 4)$ - $\alpha$-L-rhamnopyranosyl] cleroda-3,13(16), 14-diene (1), $(5 R, 6 S, 8 R, 9 S, 10 R, 13 S)$-6- $O$-[ $\beta$-D-glucopyranosyl-( $1 \rightarrow 4)$ - $\alpha$-L-rhamnopyranosyl]-2-oxoneocleroda-3,13-dien-15-ol (2), $(5 R, 6 S, 8 R, 9 S, 10 R)$-6- $O$-[ $\beta$-D-glucopyranosyl-( $1 \rightarrow 4)$ - $\alpha$-L-rhamnopyranosyl]-(13E)-2oxoneocleroda-3,14-dien-13-ol (3), together with two known compounds 4 and 5 were isolated from Dicranopteris pedata. The structures of these compounds were elucidated by detailed spectroscopic analysis, and the absolute configuration of compound $\mathbf{2}$ was determined by ECD calculations. In addition, compound $\mathbf{1}$ exhibited weak inhibitory activities against SMMC-7721, MCF-7 and SW480.
\end{abstract}

\section{Graphic Abstract}
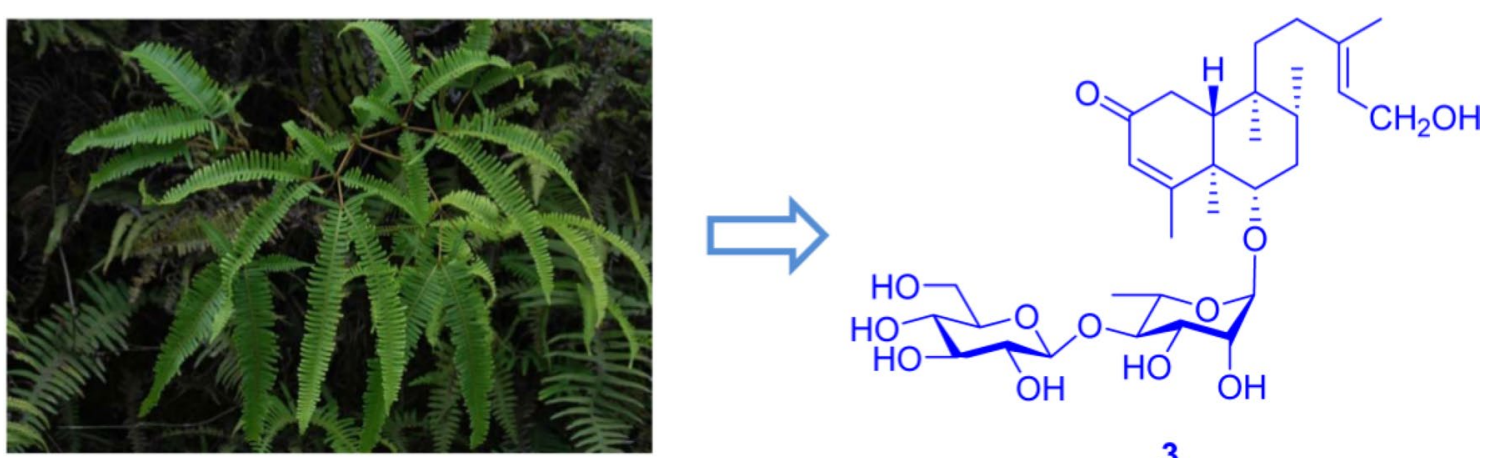

Dicranopteris pedata

Keywords Dicranopteris pedata $\cdot$ Clerodane-type diterpene glycosides $\cdot$ ECD

Bei-Bei Gao and Yu-Fei Ou have contributed equally to this work.

Qin-Shi Zhao

qinshizhao@mail.kib.ac.cn

1 Key Laboratory of Medicinal Chemistry for Natural Resource, Ministry of Education, School of Chemical Science and Technology, Yunnan University, Yunnan, 650091 Kunming, People's Republic of China

2 State Key Laboratory of Phytochemistry and Plant Resources in West China and Yunnan Key Laboratory of Natural Medicinal Chemistry, Kunming Institute of Botany, Chinese Academy of Sciences, Kunming 650201, China

3 College of Pharmacy, Guizhou Medical University, Guian New Area, Guizhou 550025, China

\section{Introduction}

The genus Dicranopteris is consists of about 10 species, distributed mainly in Asia and widely in Japan, India, Vietnam and China. There are six species in China and they mainly distribute in the south of the Yangtze River such as Yunnan, Sichuan and Guizhou provinces [1]. The whole plant of $D$. pedata is commonly used as a folk medicine in ancient China for the treatment of hemorrhage, dysentery and empyrosis $[2,3]$. Previous researches revealed a diversity of pharmacological properties of the extract of $D$. pedata, such as antioxidant, antibacterial, antinociceptive, anti-inflammatory and antipyretic activities [4-8]. Up to date, various 
secondary metabolites including flavonoids $[9,10]$, phenols [11], proanthocyanidins [12] and clerodane-type diterpene glycosides $[10,13]$ have been reported from $D$. pedata. Our previous investigation on this species revealed the presence of two oxygenated phenolic derivatives [14], dichotomains $\mathrm{A}$ and $\mathrm{B}$ and some clerodane-type diterpene glycosides, in which dichotomain A has exhibited weak anti-HIV activity $[15,16]$. As part of our ongoing search for new bioactive metabolites from fern plants, a chemical investigation on the whole plant of $D$. pedata led to the discovery of three previously undescribed compounds (1-3) (Fig. 1) and two known analogues (compounds $\mathbf{4}$ and $\mathbf{5}$ ) from the acetone extract $[15,16]$. This paper describes the details of isolation, structure identification, and cytotoxicity of compounds $\mathbf{1}-\mathbf{3}$.

\section{Results and Discussion}

Compound 1 was isolated as pale yellow powder. Its molecular formula was deduced as $\mathrm{C}_{32} \mathrm{H}_{52} \mathrm{O}_{10}$ by HRESIMS analysis (found $\mathrm{m} / \mathrm{z} 619.3454[\mathrm{M}+\mathrm{Na}]^{+}$, calcd for 619.3458), suggesting seven degrees of unsaturation. The ${ }^{13} \mathrm{C}$ and ${ }^{1} \mathrm{H}$ NMR spectra displayed two set of signals ascribed to a diterpene and two hexoses. Five methines $\left(\delta_{\mathrm{C}} 103.2,72.6,72.7,83.5,68.8\right)$ and a methyl $\left(\delta_{\mathrm{C}} 17.9\right)$ revealed the presence of rhamnose. In addition, the spectra displayed signals for a glucopyranosyl unit (five methines at $\delta_{\mathrm{C}} 105.7,76.1,78.1,71.5,78.2$ and a methylene at $\delta_{\mathrm{C}}$ 62.7). Assignment of each glycosidic proton system was achieved by analysis of ${ }^{1} \mathrm{H}-{ }^{1} \mathrm{H}$ COSY, HMBC and HSQC spectra (Fig. 2). The ${ }^{1} \mathrm{H}$ NMR spectrum of the diterpene displayed the presence of four methyls at $\delta_{\mathrm{H}} 0.73(\mathrm{~s})$, $1.08(\mathrm{~s}), 0.84(\mathrm{~d}, J=6.7 \mathrm{~Hz})$ and $1.73(\mathrm{~d}, J=1.1 \mathrm{~Hz}$, an olefinic methyl), and six olefinic protons at $\delta_{\mathrm{H}} 5.24$ (br s), $6.37(\mathrm{dd}, J=17.6,10.9 \mathrm{~Hz}), 5.20(\mathrm{~d}, J=17.6 \mathrm{~Hz}), 5.04$ $(\mathrm{d}, J=10.9 \mathrm{~Hz})$, and $4.97(2 \mathrm{H}, \mathrm{d}, J=4.4 \mathrm{~Hz})$. The signal at $\delta_{\mathrm{H}} 3.43(\mathrm{dd}, J=11.2,4.7 \mathrm{~Hz})$ could be attributed to a proton on the oxygenated carbon. Twenty carbons of the diterpene could be classified to four methyls, seven methylenes (two olefinic at $\delta_{\mathrm{C}} 113.3,116.2$ ), five methines (one oxygenated at $\delta_{\mathrm{C}} 87.7$; two olefinic at $\left.\delta_{\mathrm{C}} 123.6,140.1\right)$ and four quaternary carbons (two olefinic at $\delta_{\mathrm{C}} 144.6,148.9$ ). The structure of 1 was identified as a clerodane-type diterpenoid glycoside with two sugar moieties. Aforementioned 1D NMR resonances of $\mathbf{1}$ showed good agreement with the known compound 5 [16], except for the presence of one olefinic methylene and one olefinic quaternary carbon, together with the absence of a methyl and hydroxyl. The difference of compounds 1 and 5 lie in C-13, C-14, C-15 and C-16. The HMBC correlations (Fig. 2) from $\mathrm{H}_{2}-16\left(\delta_{\mathrm{H}}\right.$ $4.97)$ to $\mathrm{C}-12\left(\delta_{\mathrm{C}} 25.5\right), \mathrm{C}-13\left(\delta_{\mathrm{C}} 148.9\right), \mathrm{C}-14\left(\delta_{\mathrm{C}} 140.1\right)$, and $\mathrm{H}_{2}-15\left(\delta_{\mathrm{H}} 5.20,5.04\right)$ to $\mathrm{C}-13$ and $\mathrm{C}-14$, accompanied

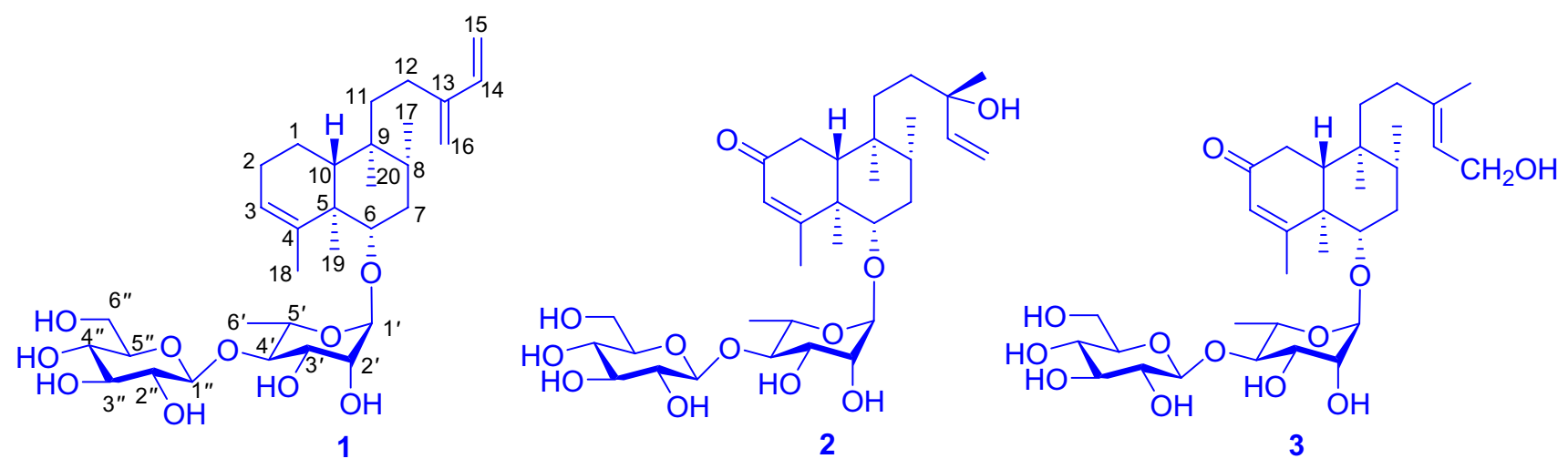

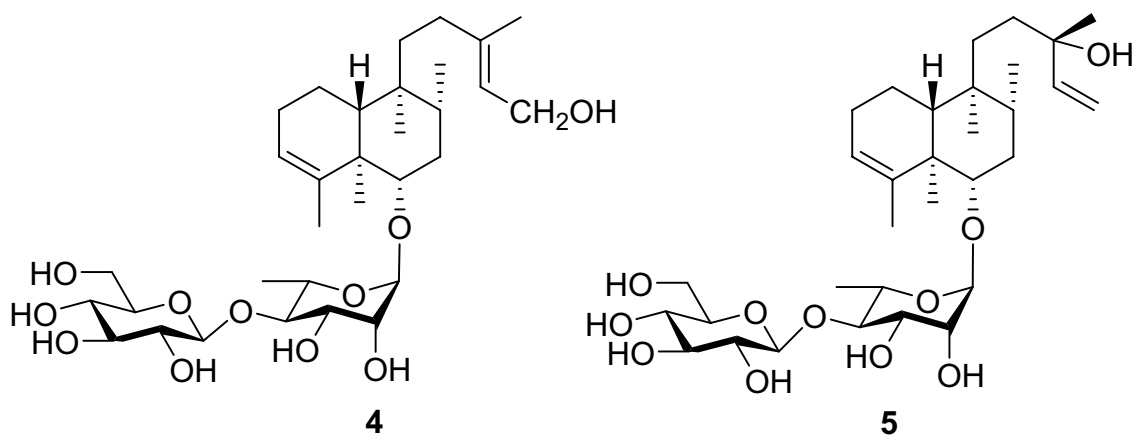

Fig. 1 Chemical structures of compounds 1-5 


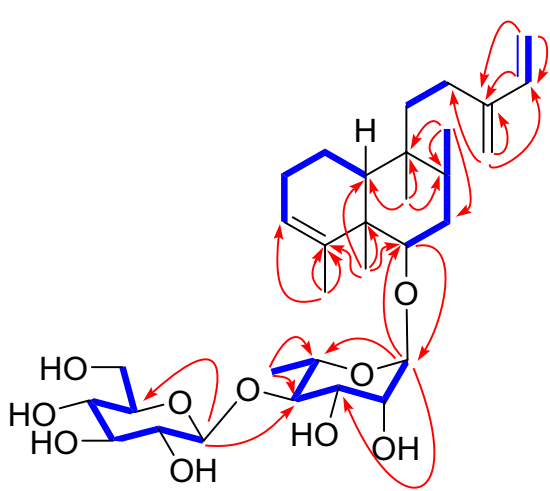

1

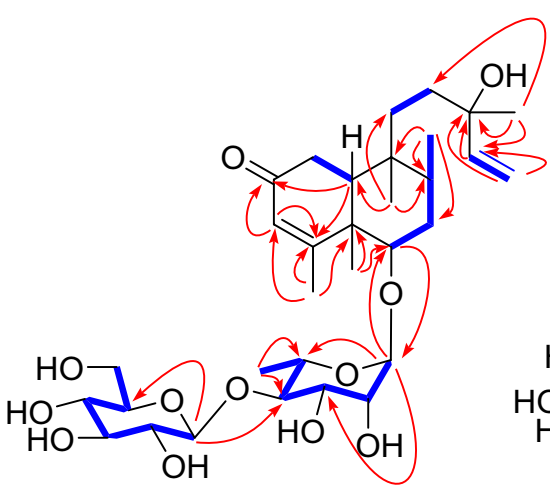

2

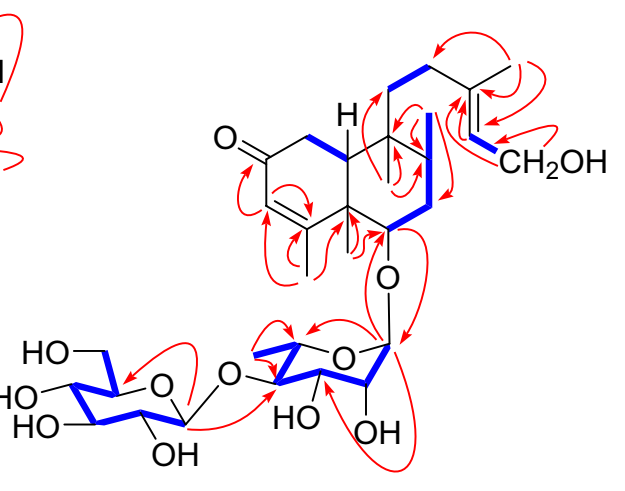

3

\section{- COSY correlations}

Fig. 2 Key ${ }^{1} \mathrm{H}-{ }^{1} \mathrm{H}$ COSY and HMBC correlations of compounds 1-3

with the ${ }^{1} \mathrm{H}-{ }^{1} \mathrm{H}$ COSY correlations (Fig. 2) between $\mathrm{H}-14$ $\left(\delta_{\mathrm{H}} 6.37\right)$ and $\mathrm{H}_{2}-15\left(\delta_{\mathrm{H}} 5.20,5.04\right)$ confirmed the existence of conjugated diene at C-13/C-16 and C-14/C-15. Thus the planar structure of compound $\mathbf{1}$ was determined.

The relative configurations of $\alpha$-rhamnopyranosyl and $\beta$-glucopyranosyl moiety were identified by the coupling constants of their anomeric protons of the rhamnopyranosyl $\left(\mathrm{H}-1^{\prime}, \delta_{\mathrm{H}} 4.79, J=1.5 \mathrm{~Hz}\right)$ and glucopyranosyl (H-1" $\delta_{\mathrm{H}} 4.59, J=7.8 \mathrm{~Hz}$ ), respectively. The location of the sugar chain was determined at C- 6 of the aglycone by $\mathrm{HMBC}$ correlations (Fig. 2) from the anomeric proton $\left(\mathrm{H}-1^{\prime}, \delta_{\mathrm{H}} 4.79\right)$ of the rhamnopyranosyl unit to C-6 $\left(\delta_{\mathrm{C}} 87.7\right)$. HMBC correlation from $\mathrm{H}-1 "{ }^{\prime \prime}\left(\delta_{\mathrm{H}} 4.59, J=7.8 \mathrm{~Hz}\right)$ to C-4' $\left(\delta_{\mathrm{C}} 83.5\right)$ defined a glucopyranosyl $(1 \rightarrow 4)$ rhamnosyl linkage. The absolute configurations of sugar moieties were determined by the experiments of acid hydrolysis, together with sugar derivatization and analysis with HPLC [16]. The retention times of the product in the test sample are consistent with that of standard sugar derivatives in HPLC (Rha derivative: $t_{\mathrm{R}}=6.68 \mathrm{~min}$; Glc derivative: $t_{\mathrm{R}}=12.78 \mathrm{~min}$ ), which gave D-glucose and L-rhamnose.

The relative configuration of $\mathbf{1}$ was assigned by analysis of its ROESY data (Fig. 4). The correlations of H-6/H-8, and $\mathrm{H}-6 / \mathrm{H}-10$ indicated that they are spatially close and were thus assigned arbitrarily as $\beta$-oriented. Consequently, the correlations of $\mathrm{CH}_{3}-19 / \mathrm{CH}_{3}-20$ revealed that they are cofacial and adopt a $\alpha$-orientation. The correlation of $\mathrm{H}-16 / \mathrm{H}-14$ disclosed the configuration of s- $(E)-13(16), 14-$ diene. The similarity of the NMR results between $\mathbf{1}$ and $\mathbf{5}$ suggests the same $(5 R, 6 S, 8 R, 9 S, 10 R)$ absolute configurations for the aglycone as previously reported. Finally, the structure of 1 was determined as $(5 R, 6 S, 8 R, 9 S, 10 R)-6$ $O$-[ $\beta$-D-glucopyranosyl- $(1 \rightarrow 4)-\alpha$-L-rhamnopyranosyl] cleroda-3,13(16),14-diene.
Compound $\mathbf{2}$ was purified as pale yellow powder with a molecular formula of $\mathrm{C}_{32} \mathrm{H}_{52} \mathrm{O}_{12}$, which was revealed by the $[\mathrm{M}+\mathrm{Na}]^{+}$ion at $m / z 651.3355$ (calcd for 651.3357), implying seven indices of hydrogen deficiency. The analysis of $1 \mathrm{D}$ NMR spectrum revealed the presence of a diterpene and two hexoses. Each glycosidic proton system was confirmed by analysis of ${ }^{1} \mathrm{H}-{ }^{1} \mathrm{H}$ COSY, HMBC and HSQC (Fig. 2). The ${ }^{1} \mathrm{H}$ NMR spectrum of the diterpene displayed the presence of five methyls, one olefinic methylene at $\delta_{\mathrm{H}} 5.16(\mathrm{dd}, J=17.4$, $1.5 \mathrm{~Hz})$ and $5.03(\mathrm{dd}, J=10.8,1.5 \mathrm{~Hz})$, two olefinic at $\delta_{\mathrm{H}}$ 5.69 (s), 5.84 (dd, $J=17.4,10.8 \mathrm{~Hz}$ ). Detailed analysis of its ${ }^{13} \mathrm{C}$ NMR and DEPT spectra revealed 20 carbons resonance which were assigned as five methyls, five methylenes (one olefinic at $\delta_{\mathrm{C}} 112.5$ ), five methines (two olefinic at $\delta_{\mathrm{C}} 127.1$, 146.1 ) and five quaternary carbons (one olefinic at $\delta_{\mathrm{C}} 175.3$ and one carbonyl at $\delta_{\mathrm{C}} 202.6$ ). The ${ }^{1} \mathrm{H}$ and ${ }^{13} \mathrm{C}$ NMR of 2 were highly analogous to 5 [16], except for the following difference: in the ${ }^{13} \mathrm{C}$ NMR spectrum, the downfield of $\mathbf{2}$ in chemical shifts of C-3 $\left(\delta_{\mathrm{C}} 127.1\right)$ and C-4 $\left(\delta_{\mathrm{C}} 175.3\right)$, together with one methylene in $\mathbf{5}$ was replaced with one carbonyl $\left(\delta_{\mathrm{C}} 202.8\right)$. This might be caused by an additional carbonyl at $\mathrm{C}-2$. In the $\mathrm{HMBC}$ spectrum, correlations could be observed from $\delta_{\mathrm{H}} 5.69(\mathrm{H}-3)$ to $\delta_{\mathrm{C}} 202.8(\mathrm{C}-2), \delta_{\mathrm{C}} 175.3$ $(\mathrm{C}-4)$ and from $\delta_{\mathrm{H}} 1.85(\mathrm{H}-10)$ to $\delta_{\mathrm{C}} 202.8(\mathrm{C}-2), \delta_{\mathrm{C}} 175.3$ (C-4). Thus, the carbonyl group was ascertained to be at C-2 position.

The presence of $\alpha$-L-rhamnose and $\beta$-D-glucose were identified by the same method as compound 1 . By the HMBC correlations of C- $6\left(\delta_{\mathrm{C}} 85\right) / \mathrm{H}-1^{\prime}\left(\delta_{\mathrm{H}} 4.86\right)$ and C-4' $\left(\delta_{\mathrm{C}} 83.3\right) / \mathrm{H}-1^{\prime \prime}\left(\delta_{\mathrm{H}} 4.86, \mathrm{~d}, J=7.8\right)$ (Fig. 2$)$, the linkage positions of the sugar moieties were confirmed. The relative configurations of the diterpene were determined the same for their similar ROESY correlations as $\mathbf{1}: \mathrm{H}-6 / \mathrm{H}-10$, H-6/H-8, and $\mathrm{CH}_{3}-19 / \mathrm{CH}_{3}-20$ (Fig. 3). Furthermore, the 


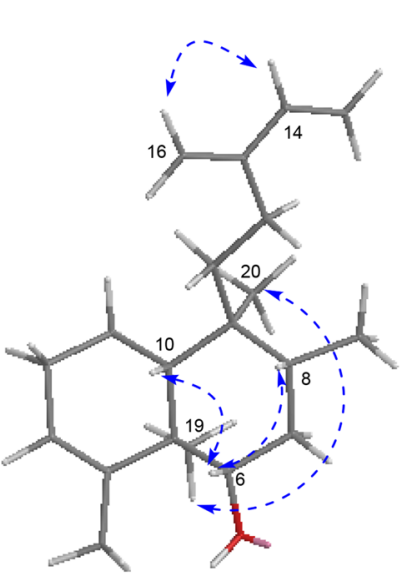

1

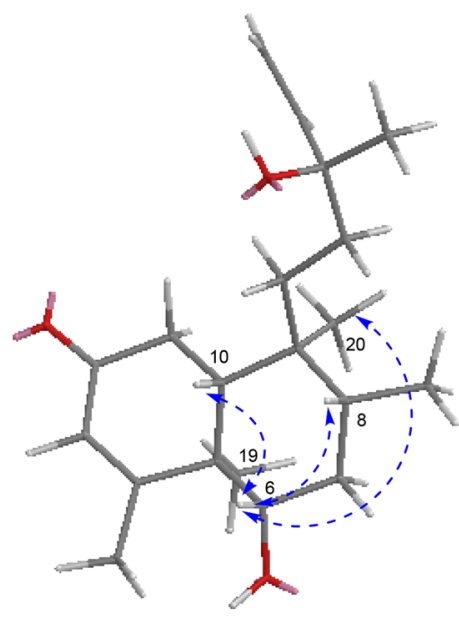

2

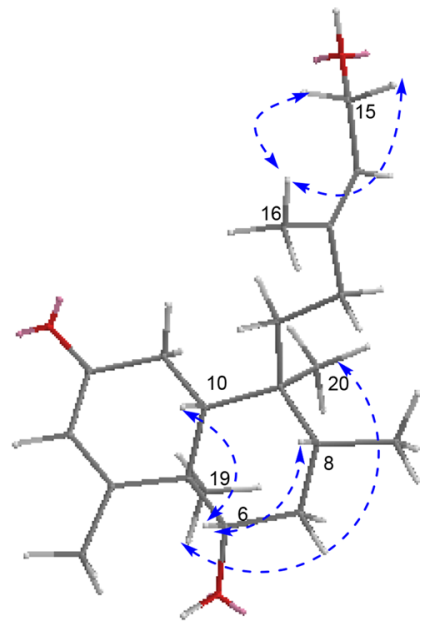

3

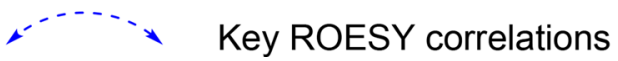

Fig. 3 Key ROESY correlations of aglycones of compounds 1-3

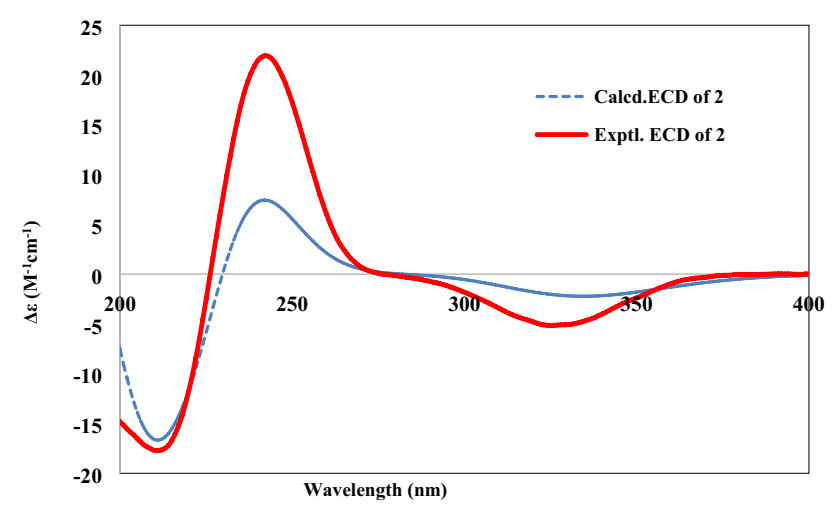

Fig. 4 The experimental and calculated ECD spectra of compound 2

absolute configuration of $\mathbf{2}$ was determined by electronic circular dichroism (ECD) experiment which fitted well with the calculated ECD (Fig. 4). Finally, the structure of 2 was determined as $(5 R, 6 S, 8 R, 9 S, 10 R, 13 S)-6-O-[\beta$ D-glucopyranosyl-( $1 \rightarrow 4)$ - $\alpha$-L-rhamnopyranosyl]-2-oxoneocleroda-3,13-dien-15-ol.

Compound 3 was obtained as pale yellow powder. It showed a molecular ion peak at $\mathrm{m} / z 651.3356[\mathrm{M}+\mathrm{Na}]^{+}$ (calcd for 651.3351), corresponding to the molecular formula of $\mathrm{C}_{32} \mathrm{H}_{52} \mathrm{O}_{12}$, which indicating seven degrees of unsaturation. The 1D NMR spectra demonstrated two hexoses and a diterpene. The spectroscopic data of the sugar moieties were consistent with $\mathbf{1}$ and $\mathbf{2}$, suggesting the presence of $\alpha$-L-rhamnopyranosyl moiety and $\beta$-Dglucopyranosyl moieties. The diterpene part involved five methyls (one at $\delta_{\mathrm{C}} 23.8$ ), five methylenes (one oxygenated at $\delta_{\mathrm{C}} 59.1$ ), five methane (one olefinic at $\delta_{\mathrm{C}}$ 125.5) and five quaternary carbons (one olefinic at $\delta_{\mathrm{C}} 140.2$ ). Those spectra suggested that the structure of $\mathbf{3}$ was highly similar to that of 2 . In comparison with $\mathbf{2}$, the chemical shifts of C-14, C-15 and C-16 decreased from $\delta_{\mathrm{C}} 146.1,112.5$ and 27.7 to $\delta_{\mathrm{C}} 125.5,59.1$ and 23.8 respectively, while C-13 increased from $\delta_{\mathrm{C}} 73.8$ to 140.2 , which testified the position of the double bond of 3 at C-13 and C-14. This was demonstrated again by the HMBC correlations of $\mathrm{H}_{2}-15 / \mathrm{C}-13$, $\mathrm{C}-14$ and $\mathrm{CH}_{3}-16 / \mathrm{C}-13, \mathrm{C}-14$. In the meantime, $\mathrm{C}-15$ was determined to be a terminal oxymethylene by the chemical shift $\left(\delta_{\mathrm{C}} 59.1\right)$ and ${ }^{1} \mathrm{H}-{ }^{1} \mathrm{H}$ COSY correlation of $\mathrm{H}_{2}-15 / \mathrm{H}-14$. Besides, the linkage of the sugar moieties was determined by the identical way with $\mathbf{1}$ and $\mathbf{2}$. Thus the plannar structure of compound $\mathbf{3}$ was determined.

The relative configuration of $\mathbf{3}$ was assigned by ROESY correlations of H-6/H-10, H-6/H-8, and $\mathrm{CH}_{3}-19 / \mathrm{CH}_{3}-20$. The ROESY correlations of $\mathrm{CH}_{3}-16 / \mathrm{H}_{2}-15$ established the $E$ configuration of the C-13/C-14 double bond. The experimental 1D and 2D NMR results of $\mathbf{2}$ and $\mathbf{3}$ were similar, which suggesting that they had the same $(R, S, R, S, R)$ absolute configuration at C-5/6/8/9/10, respectively. Finally, the structure of $\mathbf{3}$ was determined as $(5 R, 6 S, 8 R, 9 S, 10 R)-6-O-[\beta-$ D-glucopyranosyl-( $1 \rightarrow 4)-\alpha$-L-rhamnopyranosyl]-(13E)-2oxoneocleroda-3,14-dien-13-ol.

Additionally, the cytotoxicities of compounds 1-3 were evaluated against five human tumor cell lines HL-60, SMMC-7721, A-549, MCF-7 and SW-480, with cisplatin as the positive control. Compound $\mathbf{1}(40 \mu \mathrm{M})$ showed weak 
inhibitory activities in vitro against SMMC-7721, MCF-7 and SW480 with the inhibition ratio of $48.1 \%, 48.8 \%$ and $39.0 \%$, respectively. However compounds $\mathbf{2}$ and $\mathbf{3}$ did not display any activities against the tested cell lines.

\section{Conclusion}

In conclusion, this research led to the isolation of five compounds including three new and two known clerodanetype diterpene glycosides from $D$. pedata. Compounds 1-3 were assayed for their cytotoxicitives against five human tumor cell HL-60, SMMC-7721, A-549, MCF-7 and SW-480 with cisplatin as the positive control, in which compound $\mathbf{1}$ showed weak inhibitory activities in vitro against SMMC-7721, MCF-7 and SW480. This research enriched the chemical diversities of ferns.

\section{Experimental Section}

\subsection{General Experimental Procedures}

Optical rotations were carried out on Autopol VI automatoc polarimeter. UV spectra were obtained using a Shimadzu UV-2401 PC spectrophotometer. A Thermo Nicolet iS 10 spectrometer was used for measuring IR spectroscopy, which used $\mathrm{KBr}$ pellets. 1D and 2D NMR spectra were recorded on Bruker DRX-600 and spectrometers with $\mathrm{SiMe}_{4}$ (TMS) as an internal standard. Chemical shifts $(\delta)$ are expressed in ppm with reference to the solvent signals. ESI and HRESIMS were performed on an UPLCIT-TOF spectrometer. Semi-preparative HPLC was performed on an Agilent 1260 liquid chromatograph with a Zorbax SB-C18 $(9.4 \mathrm{~mm} \times 150 \mathrm{~mm})$ column. Column chromatography was carried out using silica gel (100-200 mesh, Qingdao Haiyang Chemical Co. Ltd, Qingdao, People's Republic of China) and macroporous absorption resin (DM 130, Tianjin Haoju Resin Technology Co. Ltd, people's Republic of China). Fractions were monitored by TLC, and spots were visualized by heating silica gel plates sprayed with $10 \% \mathrm{H}_{2} \mathrm{SO}_{4}$ in EtOH. The reagents used for acid hydrolysis and derivatization are listed: Trifluoroacetic acid (TFA, Beijing Yinuokai Technology Co, Ltd, Beijing, people's Republic of China); 1-Phenyl3-methyl-5-pyrazolon (PMP, analytical reagent, Tianjin Damao Chemical Reagent Factory); sodium dihydrogen phosphate $\left(\mathrm{NaH}_{2} \mathrm{PO}_{4}\right.$, analytical reagent, Tianjin Damao Chemical Reagent Factory, Tianjin, people's Republic of China); D-glucose and L-rhamnose (Qingdao Jieshikang
Biological Technology Co., Ltd, Qingdao, people's Republic of China).

\subsection{Plant Material}

The fronds of Dicranopteris pedata were collected from Huanglian Mountain, Lvchun County, Yunnan Province, People's Republic of China, in September 2019, identified by Prof. Xiao Cheng (Kunming Institute of Botany, Chinese Academy of Sciences). The voucher specimen (No. 20190921) has been deposited in State Key Laboratory of Phytochemistry and Plant Resource in West China, Kunming Institute of Botany, the Chinese Academy of Sciences.

\subsection{Extraction and Isolation of Compounds 1-5}

The dry fronds of Dicranopteris pedata $(9 \mathrm{~kg})$ were powdered and extracted with acetone $(3 \times 25 \mathrm{~L})$ for $24 \mathrm{~h}$ at room temperature. The acetone extract was concentrated under reduced pressure to yield the residue $(700 \mathrm{~g})$, which was then suspended in $\mathrm{H}_{2} \mathrm{O}$ and subjected to column chromatography over DM 130 eluting with EtOH- $\mathrm{H}_{2} \mathrm{O}(0: 10,5: 5,7: 3,5: 95$, $\mathrm{v} / \mathrm{v}), \mathrm{EtOH} / \mathrm{H}_{2} \mathrm{O}(5: 5, \mathrm{v} / \mathrm{v})$ fraction $(230 \mathrm{~g})$ was subjected to silica gel chromatography (CC) using silica gel (200-300 mesh) eluting with $\mathrm{CHCl}_{3}-\mathrm{MeOH}$ (from 12:1 to 0:1) to yield fractions A-D. Fraction B was subsequently separated on a Sephadex LH-20 CC (MeOH) to give two subfraction Fr.B $(27 \mathrm{~g})$ and Fr. $\mathrm{B}_{2}(25 \mathrm{~g})$. Fr.B $\mathrm{B}_{1}$ was divided into ten fractions (from Fr. $\mathrm{B}_{1}-1$ to Fr. $\mathrm{B}_{1}-10$ ) by using RP-C18 eluting with $\mathrm{MeOH}-\mathrm{H}_{2} \mathrm{O}$ (from 1:9 to $1: 1$ ). Fr. $_{1}-10$ was separated by $\mathrm{CC}$ on silica gel $\left(\mathrm{CHCl}_{3}-\mathrm{MeOH}, 10: 1\right)$ and further purified by semi-preparative HPLC with $\mathrm{MeCN}-\mathrm{H}_{2} \mathrm{O}(23: 77$, v/v) to obtain compound $2\left(6 \mathrm{mg}, t_{\mathrm{R}}=44.11 \mathrm{~min}\right)$. Compound $4\left(4 \mathrm{mg}, t_{\mathrm{R}}=26.70 \mathrm{~min}\right)$ and $\mathbf{5}\left(3 \mathrm{mg}, t_{\mathrm{R}}=31.35 \mathrm{~min}\right)$ were obtained by $\mathrm{MeOH}-\mathrm{H}_{2} \mathrm{O}(40: 60, \mathrm{v} / \mathrm{v})$. Compound 3 was separated and purified from Fr. $\mathrm{B}_{1}-8$ by semi-preparative HPLC with $\mathrm{MeOH}-\mathrm{H}_{2} \mathrm{O}\left(48: 52\right.$, v/v). Fr. $\mathrm{B}_{1}-9$ was separated by CC on silica gel $\left(\mathrm{CHCl}_{3}-\mathrm{MeOH}, 20: 1\right.$ to $\left.15: 1\right)$ and further purified by semi-preparative HPLC with $\mathrm{MeOH}-\mathrm{H}_{2} \mathrm{O}$ (75:25, $\mathrm{v} / \mathrm{v})$ to give compound $1\left(4 \mathrm{mg}, t_{\mathrm{R}}=36.11 \mathrm{~min}\right)$.

\subsection{Spectroscopy Data of Compounds 1-3}

$(5 R, 6 S, 8 R, 9 S, 10 R)-6-O-[\beta$-D-glucopyranosyl- $(1 \rightarrow 4)-\alpha$-Lrhamnopyranosyl]cleroda-3,13(16),14-diene (1): pale yellow powder; $[\alpha]_{\mathrm{D}}^{26}-25.8(c, 0.26, \mathrm{MeOH})$; UV $(\mathrm{MeOH})$ $\lambda_{\max }(\log \varepsilon): 196.5$ (3.26), 208.0 (3.17), 223.5 (3.27); IR $\left(\nu_{\max }\right): 3402,3090,2956,2926,2875 \mathrm{~cm}^{-1}$; HRESIMS at $\mathrm{m} / \mathrm{z} 619.3454[\mathrm{M}+\mathrm{Na}]^{+}$(calcd for 619.3458$) .{ }^{1} \mathrm{H}$ and ${ }^{13} \mathrm{C}$ NMR data, see Tables 1 and 2.

$(5 R, 6 S, 8 R, 9 S, 10 R, 13 S$ ) - $6-O-[\beta-\mathrm{D}$ glucopyranosyl-( $1 \rightarrow 4)$ - $\alpha$-L-rhamnopyranosyl]-2oxoneocleroda-3,13-dien-15-ol (2): pale yellow powder; 
Table $1{ }^{1} \mathrm{H}$ NMR $(600 \mathrm{~Hz})$ data ( $\delta$ in ppm, $J$ in $\mathrm{Hz}$ ) for compounds $\mathbf{1}-\mathbf{3}$ in $\mathrm{CD}_{3} \mathrm{OD}$

\begin{tabular}{|c|c|c|c|}
\hline NO. & $\begin{array}{l}1 \\
\delta_{\mathrm{H}}, \text { mult }(J)\end{array}$ & $\begin{array}{l}2 \\
\delta_{\mathrm{H}}, \text { mult }(J)\end{array}$ & $\begin{array}{l}3 \\
\delta_{\mathrm{H}}, \text { mult }(J)\end{array}$ \\
\hline 1 & 1.61 (overlapped) & $\beta, 2.51, \mathrm{dd}(17.9,13.9)$ & $\beta, 2.59, \mathrm{dd}(17.8,14.0)$ \\
\hline 1 & & $\alpha, 2.28, \mathrm{dd}(17.9,3.2)$ & $\alpha, 2.33, \mathrm{dd}(17.8,2.9)$ \\
\hline 2 & 2.03 (overlapped) & & \\
\hline 3 & 5.24 , br s & $5.69, \mathrm{~s}$ & $5.71, \mathrm{~s}$ \\
\hline 6 & $3.43, \mathrm{dd}(11.2,4.7)$ & 3.64 (overlapped) & 3.68 (overlapped) \\
\hline \multirow[t]{2}{*}{7} & $\beta, 2.03$ (overlapped) & $\beta, 2.12, \mathrm{~m}$ & $\beta, 2.16$, dd $(10.4,4.6)$ \\
\hline & $\alpha, 1.59$ (overlapped) & $\alpha, 1.68, \mathrm{~m}$ & $\alpha, 1.71$ (overlapped) \\
\hline 8 & 1.70 (overlapped) & $1.62, \mathrm{~m}$ & 1.73 (overlapped) \\
\hline 10 & 1.42 (overlapped) & $1.85, \mathrm{dd}(13.9,3.4)$ & 1.95 (overlapped) \\
\hline \multirow[t]{2}{*}{11} & $\beta, 1.54, \mathrm{~m}$ & $\beta, 1.36$ (overlapped) & 1.35 (overlapped) \\
\hline & $\alpha, 1.44$ (overlapped) & $\alpha, 1.27$ (0verlapped) & \\
\hline \multirow[t]{2}{*}{12} & $\beta, 2.10, \operatorname{td}(13.2,4.1)$ & $\beta, 1.37$ (overlapped) & $\beta, 1.95$ (overlapped) \\
\hline & $\alpha, 1.98(\mathrm{~m})$ & $\alpha, 1.17$ (overlapped) & $\alpha, 1.74(\mathrm{~m})$ \\
\hline 14 & $6.37, \mathrm{dd}(17.6,10.9)$ & $5.84, \mathrm{dd}(17.4,10.8)$ & $5.33, \mathrm{t}(6.8)$ \\
\hline \multirow[t]{2}{*}{15} & $\beta, 5.20, \mathrm{~d}(17.6)$ & $\beta, 5.16, \mathrm{dd}(17.4,1.5)$ & $4.0, \mathrm{~d}(6.9)$ \\
\hline & $\alpha, 5.04, \mathrm{~d}(10.9)$ & $\alpha, 5.03, \mathrm{dd}(10.8,1.5)$ & \\
\hline 16 & 4.97, d (4.4) & $1.22, \mathrm{~s}$ & $1.72, \mathrm{~s}$ \\
\hline 17 & $0.84, \mathrm{~d}(6.7)$ & 0.85 (overlapped) & $0.89, \mathrm{~d}(6.1)$ \\
\hline 18 & $1.73, \mathrm{~d}(1.1)$ & $2.06, \mathrm{~d}(2.06)$ & $2.08, \mathrm{~s}$ \\
\hline 19 & $1.08, \mathrm{~s}$ & $1.17, \mathrm{~s}$ & $1.20, \mathrm{~s}$ \\
\hline 20 & $0.73, \mathrm{~s}$ & 0.84 (overlapped) & $0.84, \mathrm{~s}$ \\
\hline \multicolumn{4}{|l|}{ Rha } \\
\hline $1^{\prime}$ & $4.79, \mathrm{~d}(1.5)$ & 4.86 (overlapped) & 4.88 (overlapped) \\
\hline $2^{\prime}$ & 3.84 (overlapped) & 3.84 (overlapped) & 3.85 (overlapped) \\
\hline $3^{\prime}$ & 3.88 , dd $(9.4,3.2)$ & 3.88, dd $(9.3,3.2)$ & 3.89 , dd $(9.3,3.2)$ \\
\hline $4^{\prime}$ & $3.62, \mathrm{t}(9.5)$ & 3.62 , (overlapped) & $3.65, \mathrm{t}(9.7)$ \\
\hline $5^{\prime}$ & $3.78, \mathrm{~m}$ & $3.77, \mathrm{~m}$ & $3.77, \mathrm{~m}$ \\
\hline $6^{\prime}$ & $1.31, \mathrm{~d}(6.3)$ & $1.32, \mathrm{~d}(6.2)$ & $1.33, \mathrm{~d}(6.2)$ \\
\hline \multicolumn{4}{|l|}{ Glc } \\
\hline $1^{\prime \prime}$ & $4.59, \mathrm{~d}(7.8)$ & $4.59, \mathrm{~d}(7.8)$ & $4.60, \mathrm{~d}(7.8)$ \\
\hline $2^{\prime \prime}$ & $3.20, \mathrm{dd}(9.1,7.9)$ & 3.21 , dd $(9.1,7.9)$ & $3.21, \mathrm{~m}$ \\
\hline $3 "$ & $3.36, \mathrm{dd}(15.8,6.9)$ & $3.36, \mathrm{~m}$ & $3.36, \mathrm{~m}$ \\
\hline $4 "$ & 3.29 (overlapped) & 3.29 (overlapped) & 3.29 (overlapped) \\
\hline $5 "$ & $3.26, \mathrm{~m}$ & $3.26, \mathrm{~m}$ & $3.26, \mathrm{~m}$ \\
\hline \multirow[t]{2}{*}{$6 "$} & $\beta, 3.85$ (overlapped) & $\beta, 3.85$ (overlapped) & $\beta, 3.84$ (overlapped) \\
\hline & $\alpha, 3.69$, dd $(11.9,5.2)$ & $\alpha, 3.69, \mathrm{dd}(11.8,5.2)$ & $\alpha, 3.69, \mathrm{dd}$ (overlapped) \\
\hline
\end{tabular}

$[\alpha]_{26}^{\mathrm{D}}-37.98(c, 0.10, \mathrm{MeOH}) ; \mathrm{UV}(\mathrm{MeOH}) \lambda_{\max }(\log \varepsilon)$ : 195.5 (3.13), 209.0 (3.02), 238.5 (3.35); ECD (MeOH) $\lambda_{\text {max }}(\Delta \varepsilon) 245$ (21.24); IR $\left(\nu_{\max }\right): 3387,2964,2926,2878$, $1652 \mathrm{~cm}^{-1}$; HRESIMS at $\mathrm{m} / z$, $651.3355[\mathrm{M}+\mathrm{Na}]^{+}$(calcd for 651.3357); ${ }^{1} \mathrm{H}$ and ${ }^{13} \mathrm{C}$ NMR data see Tables 1 and 2.

( $5 R, 6 S, 8 R, 9 S, 10 R$ ) - 6 - $O$ - [ $\beta$ - D glucopyranosyl-( $1 \rightarrow 4)$ - $\alpha$-L-rhamnopyranosyl]-(13E)-2oxoneocleroda-3,14-dien-13-ol (3): pale yellow powder; $[\alpha]_{26}^{\mathrm{D}}-18.9(c, 0.26, \mathrm{MeOH}) ; \mathrm{UV}(\mathrm{MeOH}) \lambda_{\max }(\log \varepsilon)$ : 196.0 (3.32), 215.0 (2.99), 238.0 (3.19); IR ( $\left.\nu_{\max }\right): 3404$, 2964, 2928, 1716, $1651 \mathrm{~cm}^{-1}$; HRESIMS at $\mathrm{m} / \mathrm{z} 651.3356$
$[\mathrm{M}+\mathrm{Na}]^{+}$(calcd for 651.3351$) .{ }^{1} \mathrm{H}$ and ${ }^{13} \mathrm{C}$ NMR data see Tables 1 and 2.

\subsection{Acid Hydrolysis and Derivatization}

Compounds 1-3 were hydrolyzed with trifluoroacetic acid (TFA) by the procedure of the previous reported [17], with minor modifications. Compound 1 ( $2 \mathrm{mg}, 3.35 \mu \mathrm{mol})$ was dissolved in $2 \mathrm{M}$ TFA ( $2 \mathrm{~mL})$, after the reaction mixture was heated to $120^{\circ} \mathrm{C}$ and stirred for $2 \mathrm{~h}$ before cooling to room temperature. Then, extracted with $\mathrm{CHCl}_{3}(3 \times 1 \mathrm{~mL})$ and 
Table $2{ }^{13} \mathrm{C}$ NMR $(150 \mathrm{~Hz})$ data ( $\delta$ in ppm) for compounds 1-3 in $\mathrm{CD}_{3} \mathrm{OD}$

\begin{tabular}{|c|c|c|c|c|c|c|}
\hline \multirow[t]{2}{*}{ NO } & \multicolumn{2}{|l|}{1} & \multicolumn{2}{|l|}{2} & \multicolumn{2}{|l|}{3} \\
\hline & $\delta_{\mathrm{C}}$ & Type & $\delta_{\mathrm{C}}$ & Type & $\delta_{\mathrm{C}}$ & Type \\
\hline 1 & 18.9 & $\mathrm{CH}_{2}$ & 35.0 & $\mathrm{CH}_{2}$ & 35.2 & $\mathrm{CH}_{2}$ \\
\hline 2 & 27.7 & $\mathrm{CH}_{2}$ & 202.8 & $\mathrm{C}$ & 202.6 & $\mathrm{C}$ \\
\hline 3 & 123.6 & $\mathrm{CH}$ & 127.1 & $\mathrm{CH}$ & 127.1 & $\mathrm{CH}$ \\
\hline 4 & 144.6 & $\mathrm{C}$ & 175.3 & C & 175.2 & $\mathrm{C}$ \\
\hline 5 & 45.1 & $\mathrm{C}$ & 46.6 & C & 46.7 & $\mathrm{C}$ \\
\hline 6 & 87.7 & $\mathrm{CH}$ & 85.0 & $\mathrm{CH}$ & 85.0 & $\mathrm{CH}$ \\
\hline 7 & 36.1 & $\mathrm{CH}_{2}$ & 35.6 & $\mathrm{CH}_{2}$ & 35.5 & $\mathrm{CH}_{2}$ \\
\hline 8 & 35.4 & $\mathrm{CH}$ & 34.9 & $\mathrm{CH}$ & 34.9 & $\mathrm{CH}$ \\
\hline 9 & 39.4 & $\mathrm{C}$ & 39.0 & $\mathrm{C}$ & 39.5 & $\mathrm{C}$ \\
\hline 10 & 47.1 & $\mathrm{CH}$ & 46.4 & $\mathrm{CH}$ & 46.5 & $\mathrm{CH}$ \\
\hline 11 & 39.1 & $\mathrm{CH}_{2}$ & 32.4 & $\mathrm{CH}_{2}$ & 37.3 & $\mathrm{CH}_{2}$ \\
\hline 12 & 25.5 & $\mathrm{CH}_{2}$ & 35.5 & $\mathrm{CH}_{2}$ & 25.8 & $\mathrm{CH}_{2}$ \\
\hline 13 & 148.9 & $\mathrm{C}$ & 73.8 & $\mathrm{C}$ & 140.2 & $\mathrm{C}$ \\
\hline 14 & 140.1 & $\mathrm{CH}$ & 146.1 & $\mathrm{CH}$ & 125.5 & $\mathrm{CH}$ \\
\hline 15 & 113.3 & $\mathrm{CH}_{2}$ & 112.5 & $\mathrm{CH}_{2}$ & 59.1 & $\mathrm{CH}_{2}$ \\
\hline 16 & 116.2 & $\mathrm{CH}_{2}$ & 27.7 & $\mathrm{CH}_{3}$ & 23.8 & $\mathrm{CH}_{2}$ \\
\hline 17 & 16.3 & $\mathrm{CH}_{3}$ & 15.9 & $\mathrm{CH}_{3}$ & 16.0 & $\mathrm{CH}_{3}$ \\
\hline 18 & 23.3 & $\mathrm{CH}_{3}$ & 23.5 & $\mathrm{CH}_{3}$ & 23.6 & $\mathrm{CH}_{3}$ \\
\hline 19 & 16.6 & $\mathrm{CH}_{3}$ & 14.9 & $\mathrm{CH}_{3}$ & 14.8 & $\mathrm{CH}_{3}$ \\
\hline 20 & 18.3 & $\mathrm{CH}_{3}$ & 17.9 & $\mathrm{CH}_{3}$ & 17.7 & $\mathrm{CH}_{3}$ \\
\hline \multicolumn{7}{|c|}{ Rha } \\
\hline $1^{\prime}$ & 103.2 & $\mathrm{CH}$ & 103.0 & $\mathrm{CH}$ & 103.0 & $\mathrm{CH}$ \\
\hline $2^{\prime}$ & 72.6 & $\mathrm{CH}$ & 72.5 & $\mathrm{CH}$ & 72.5 & $\mathrm{CH}$ \\
\hline $3^{\prime}$ & 72.7 & $\mathrm{CH}$ & 72.6 & $\mathrm{CH}$ & 72.6 & $\mathrm{CH}$ \\
\hline $4^{\prime}$ & 83.5 & $\mathrm{CH}$ & 83.3 & $\mathrm{CH}$ & 83.4 & $\mathrm{CH}$ \\
\hline $5^{\prime}$ & 68.8 & $\mathrm{CH}$ & 68.9 & $\mathrm{CH}$ & 69.0 & $\mathrm{CH}$ \\
\hline $6^{\prime}$ & 17.9 & $\mathrm{CH}_{3}$ & 17.9 & $\mathrm{CH}_{3}$ & 17.9 & $\mathrm{CH}_{3}$ \\
\hline \multicolumn{7}{|l|}{ Glc } \\
\hline $1^{\prime \prime}$ & 105.7 & $\mathrm{CH}$ & 105.7 & $\mathrm{CH}$ & 105.7 & $\mathrm{CH}$ \\
\hline $2^{\prime \prime}$ & 76.1 & $\mathrm{CH}$ & 76.1 & $\mathrm{CH}$ & 76.1 & $\mathrm{CH}$ \\
\hline $3 "$ & 78.1 & $\mathrm{CH}$ & 78.1 & $\mathrm{CH}$ & 78.1 & $\mathrm{CH}$ \\
\hline $4^{\prime \prime}$ & 71.5 & $\mathrm{CH}$ & 71.5 & $\mathrm{CH}$ & 71.5 & $\mathrm{CH}$ \\
\hline $5^{\prime \prime}$ & 78.2 & $\mathrm{CH}$ & 78.2 & $\mathrm{CH}$ & 78.2 & $\mathrm{CH}$ \\
\hline $6^{\prime \prime}$ & 62.7 & $\mathrm{CH}_{2}$ & 62.7 & $\mathrm{CH}_{2}$ & 62.7 & $\mathrm{CH}_{2}$ \\
\hline
\end{tabular}

$\left(t_{\mathrm{R}}=6.67 \mathrm{~min}\right)$, showing retention times consistent with the standard monosaccharide derivatives.

\subsection{Cytotoxicity Assay}

MTT assays [18] were used to evaluating the cytotoxicities of compounds 1-3. Five human tumor cell lines including leukemia HL-60, liver cancer SMMC-7721, lung cancer A-549, breast cancer MCF-7 and colon cancer SW-480, were incubated in RMPI-1640 or DMEM medium supplemented with $10 \%$ fetal bovine serum and seeded at $3-15 \times 10^{3}$ cells each well of a 96-well cell culture plate. After $12-24 \mathrm{~h}$ of incubation at $37^{\circ} \mathrm{C}$, the tested compound $(40 \mu \mathrm{M}$, dissolved in DMSO) was added. After incubated for $48 \mathrm{~h}$, each well 
were added $20 \mu \mathrm{L}$ MTS [3-(4,5-dimethylthiazol-2-yl)-5-(3carboxymethoxyphenyl)-2-(4-sulfophenyl)-2H-tetrazolium, inner salt]. Then, they were cultured for further $4 \mathrm{~h}$. The cisplatin was applied as the positive control. The MULTISKAN FC was used to measure the OD value at $492 \mathrm{~nm}$.

Supplementary Information The online version contains supplementary material available at https://doi.org/10.1007/s13659-021-00315-y.

Acknowledgements This work is supported by the Natural Science Foundation of Yunnan province. (No. 202001AT070052)

Data Availability This article is licensed under a Creative Commons Attribution 4.0 International License, which permits to use, sharing, adaptation, distribution and reproduction in any medium or format, as long as you give appropriate credit to the original author (s) and the source, provide a link to the Creative Commons licence, and indicate if changes were made. The images or other third party material in this article are included in the article's Creative Commons licence, unless indicated otherwise in a credit line to the material. If material is not included in the article's Creative Commons licence and your intended use is not permitted by statutory regulation or exceeds the permitted use, you will need to obtain permission directly from the copyright holder. To view a copy of this licence, visit http://creativecommons. org/licenses/by/4.0/.

\section{Declarations}

Conflict of interest All authors declare no conflict of interest.

Open Access This article is licensed under a Creative Commons Attribution 4.0 International License, which permits use, sharing, adaptation, distribution and reproduction in any medium or format, as long as you give appropriate credit to the original author(s) and the source, provide a link to the Creative Commons licence, and indicate if changes were made. The images or other third party material in this article are included in the article's Creative Commons licence, unless indicated otherwise in a credit line to the material. If material is not included in the article's Creative Commons licence and your intended use is not permitted by statutory regulation or exceeds the permitted use, you will need to obtain permission directly from the copyright holder. To view a copy of this licence, visit http://creativecommons.org/licenses/by/4.0/.

\section{References}

1. Editorial Committee of the Flora of China of Chinese Academy of Science, Flora of China, Vol. 2 (3) (Science Press, Beijing, 1980), pp. 118-119

2. Editorial Board of China Herbal, State Administration of Traditional Chinese Medicine, China Herbal, Vol. 4 (2) (Scientific and Technical Publishers, Shanghai, 1999), pp. 86-87

3. Q.J. Li, Z.H. Ni, Y. Yang, X.J. Hao, X.S. Yang, Chin. Pharm. J. 51, 1274-1277 (2016)

4. L.J. Ding, Z.H. Zhou, Y.R. Lin, Food Science 26, 77-82 (2005)

5. Y.C. Su, Subtrop. Plant. Sci. 34, 43-45 (2005)

6. Z.A. Zakaria, Z.D.F.A. Ghani, R.N.S.R.M. Nor, H.K. Gopalan, M.R. Sulaiman, A.M.M. Jais, M.N. Somchit, A.A. Kader, J. Ripin, J. Nat. Med. 62, 179-187 (2008)

7. Z.A. Zakaria, Z.D.F. Abdul Ghani, R.N.S.R.M. Nor, H.K. Gopalan, M.R. Sulaiman, F.C. Abdullah, Yakugaku Zasshi 126, 1197 $1203(2006)$

8. Z.A. Zakaria, F.H. Kamisan, M.H. Omar, N.D. Mahmood, F. Othman, S.S. Abdul Hamid, M.N.H. Abdullah, BMC. Complement. Altern. Med. 17, 271-285 (2017)

9. Y. Kishimoto, Yakugaku Zasshi 75, 1437-1439 (1955)

10. P.R. Diraviam, S.M. Visuvasam, J.B. Alexis, G. Subarayan, U. Toshiyuki, S. Masako, T. Akinobu, F. Hiroyuki, T. Nobutoshi, Chem. Pharm. Bull. 43, 1800-1803 (1995)

11. T. Kuraishi, Y. Mitadera, T. Murakami, N. Tanaka, Y. Saiki, C.M. Chen, Yakugaku Zasshi 103, 679-682 (1983)

12. K. Yoshiki, M. Masafumi, N. Gen-ichiro, N. Itsuo, Chem. Pharm. Bull. 38, 856-860 (1990)

13. A. Tadashi, O. Tadashi, H. Yoshikazu, S. Takayuki, U. Mihoko, O. Shinji, Phytochemistry 46, 839-844 (1997)

14. X.L. Li, X. Cheng, L.M. Yang, R.R. Wang, Y.T. Zheng, W.L. Xiao, Y. Zhao, G. Xu, Y. Lu, Y. Chang, Q.T. Zheng, Q.S. zhao, H.D. Sun, Org. Lett. 8, 1937-1940 (2006)

15. X.L. Li, L.M. Yang, Y. Zhao, R.R. Wang, G. Xu, Y.T. Zheng, L. Tu, L.Y. Peng, X. Cheng, Q.S. Zhao, J. Nat. Prod. 70, 265-268 (2007)

16. X.L. Li, L. Tu, Y. Zhao, L.Y. Peng, G. Xu, X. Cheng, Q.S. Zhao. Helv. Chim. Acta. 91, 856-861 (2008)

17. X.Y. Wang, A.N. Gao, Y.D. Jiao, Y. Zhao, X.B. Yang, Int. J. Biol. Macromol. 108, 625-634 (2018)

18. A.H. Cory, Cancer Commun. 3, 207-212 (1991) 